\title{
Elevated Ferritin Levels and the Relationship with Fasting Insulin Levels in Elderly Patients with Metabolic Syndrome
}

\author{
Fulden Sarac1 ${ }^{*}$, Sumru Savas ${ }^{1}$, Sefa Sarac ${ }^{2}$, Fehmi Akcicek ${ }^{1}$ \\ ${ }^{1}$ Department of Internal Medicine, Section of Geriatrics, Medical Faculty, Ege University, Izmir, Turkey \\ ${ }^{2}$ Department of Cardiology, Katip Celebi University, Ataturk Training and Research Hospital, Izmir, Turkey \\ Email: fuldensarac@yahoo.com
}

Received 19 June 2014; revised 15 July 2014; accepted 11 August 2014

Copyright (C) 2014 by authors and Scientific Research Publishing Inc.

This work is licensed under the Creative Commons Attribution International License (CC BY).

http://creativecommons.org/licenses/by/4.0/

(c) (i) Open Access

\begin{abstract}
Introduction: Elevated serum ferritin levels are associated with insulin resistance, type 2 diabetes and metabolic syndrome (MetS) as well as systemic inflammation and cardiovascular disease. The associations between ferritin and hemoglobin levels with individual components of MetS are unclear. The aims of the study were 1) to compare the ferritin levels, and 2) to investigate the relationships between ferritin, high-sensitivity CRP (hs-CRP), fasting glucose, fasting insulin and homeostasis model assessment (HOMA-IR) levels in elderly patients. Subjects and Methods: Study population included 121 (mean age $64.3 \pm 14.1 \mathrm{yrs}$ ) (80 female, 41 male) elderly patients. The study population was evaluated for MetS by Adult Treatment Panel III (ATPIII). Demographic and biochemical data such as fasting insulin, hs-CRP, fasting glucose and ferritin levels were evaluated. Biochemical data were evaluated retrospectively. Insulin resistance (IR) was estimated using the HOMA. Results: Metabolic syndrome was diagnosed in 39 elderly patients (32.2\%). In elderly patients with MetS, mean levels of ferritin, hs-CRP, fasting glucose, fasting insulin and HOMA were found to be $72.9 \pm 33.1 \mathrm{ng} / \mathrm{ml}, 0.90 \pm 0.01,99.1 \pm 20.1 \mathrm{mg} / \mathrm{dl}, 13.4 \pm 1.1 \mu \mathrm{U} / \mathrm{l}, 3.0 \pm 0.1$, respectively. However, mean levels of ferritin, hs-CRP, fasting glucose, fasting insulin and HOMA were found to be $54.1 \pm 33.1 \mathrm{ng} / \mathrm{ml}, 0.67 \pm 0.1,91.9 \pm 17.0 \mathrm{mg} / \mathrm{dl}, 8.4 \pm 2.7 \mu \mathrm{U} / \mathrm{l}, 2.71 \pm 0.9$, in the other elderly patients, $(p=0.0012),(p=0.70),(p=0.70),(p=0.003),(p=0.80)$ respectively. Mean levels of ferritin were positively correlated with diastolic $(r=0.850, p=0.03)$, systolic blood pressures $(r=$ $0.700, p=0.02)$, and fasting insulin $(r=0.444, p=0.003)$ in elderly with MetS. Conclusions: Mean levels of ferritin were increased in elderly patients with metabolic syndrome. And also, ferritin levels were positively correlated with systolic and diastolic blood pressures as well as fasting insulin but not with hs-CRP levels in elderly patients with metabolic syndrome.
\end{abstract}

\footnotetext{
${ }^{*}$ Corresponding author.
}

How to cite this paper: Sarac, F., Savas, S., Sarac, S. and Akcicek, F. (2014) Elevated Ferritin Levels and the Relationship with Fasting Insulin Levels in Elderly Patients with Metabolic Syndrome. Journal of Diabetes Mellitus, 4, 242-248. 


\section{Keywords}

\section{Metabolic Syndrome, Ferritin, Fasting Insulin, Elderly}

\section{Introduction}

Increasing life expectancy is a worldwide phenomenon and has led to a progressive increase in the proportion of elderly people [1]. Iron is one of the essential inorganic substances for normal body physiology [2]. However, iron overload may be associated with adverse health outcomes [3]. Elevated serum ferritin levels are associated with insulin resistance [4]-[6], metabolic syndrome (MetS) [7] [8] systemic inflammation [4] [5], type 2 diabetes [9], and cardiovascular disease [10]. The associations between ferritin and hemoglobin levels with individual MetS components are unclear. Increased body iron may contribute to insulin resistance through mechanisms related to both reduced extraction of insulin and impaired insulin secretion [11]. Many studies have shown that subclinical iron overload in nonpathologic conditions leads to insulin resistance and an increased risk of type 2 diabetes mellitus [11]-[16]. Previously, Tuomainen et al. [17] suggested that serum ferritin levels were correlated with fasting serum glucose and insulin concentrations. In a latter study, it was found that there were significant positive correlations between the levels of ferritin, homeostasis model assessment of insulin resistance (HOMA-IR) and $\beta$-cell function (HOMA\%B) [18]. However, according to our knowledge there are no efficient studies evaluating the characteristics of ferritin, fasting glucose, fasting insulin and HOMA-IR levels in elderly patients with or without MetS. Therefore, the aims of the study were 1) to compare the ferritin levels, and 2) to investigate the relationships between ferritin, high-sensitivity CRP (hs-CRP), fasting glucose, fasting insulin and HOMA-IR levels in elderly patients.

\section{Subjects and Methods}

Study population consisted of 300 consecutive patients over fifty years of age referred to outpatient clinic of internal medicine department of Ege University Hospital from January 1st, 2014 to April 8th, 2014.

Subjects with neoplastic disease, history of chronic inflammatory disease, acute infectious disease, anemia, abnormal liver enzyme levels (aspartate aminotransferase, AST and/or alanine aminotransferase, ALT $\geq 2.5 \times$ upper limit of normal value), increased serum creatinine $(>1.4 \mathrm{mg} / \mathrm{dl}$ ) and also high serum ferritin levels (>800 $\mathrm{ng} / \mathrm{ml}$ ) as well as high hs-CRP (greater than $1.0 \mathrm{mg} / \mathrm{dl}$ ) levels were excluded. Finally 121 patients (mean age $64.3 \pm 14.1$ yrs) (80 female, 41 male) were included in the study. All study population was evaluated for MetS by Adult Treatment Panel III (ATPIII) [19]. Anthropometric measurements were made in all subjects such as body weight $(\mathrm{kg})$, body mass index $\left(\mathrm{BMI}, \mathrm{kg} / \mathrm{m}^{2}\right)$ and waist circumference $(\mathrm{cm})$.

Habitual alcohol consumption and smoking were inquired with the following two questions: "Do you drink alcohol at least once a month? Yes/ No". "Do you smoke? Yes/No". If the answer is Yes, smokers were classified into two categories as ex-smokers and non-smokers [20].

Demographic and biochemical data such as fasting insulin, fasting glucose and ferritin levels were evaluated, retrospectively. High-sensitivity CRP was determined by a chemiluminescent assay on the Immulite analyzer (Diagnostic Products Corporation, Los Angeles, CA, USA). Serum ferritin was determined by an ELISA (Diagnostic Systems Laboratories, Webster, TX, USA). Insulin levels were measured with chemmiluminance. Insulin resistance was calculated using the HOMA-IR as described by Matthews et al. [21] as follows: fasting serum insulin $(\mu \mathrm{U} / \mathrm{mL}) \times$ fasting serum glucose $(\mathrm{mg} / \mathrm{dL}) / 22.5$.

The study was approved by local Ethics Committee and informed consent was taken from the participants before they were taken into the study.

\section{Statistical Analysis}

Statistical analysis was performed using the SPSS for Windows (13.0) software package. Data were expressed as mean \pm standard deviation (SD). The groups were compared using the Mann Whitney test. Pearson correlation coefficients were calculated to identify associations of clinical variables. 


\section{Results}

Metabolic syndrome was diagnosed in 39 elderly patients (32.2\%). Elderly patients without MetS were accepted as control group. Of 39 patients with MetS, 11 (28.2\%) had a history of cardiovascular disease, 19 (48.7\%) had dyslipidemia, 14 (35.8\%) had hypertension and 6 (15.3\%) had type 2 diabetes mellitus. In the control group, 10 (12.1\%) had a family history of cardiovascular disease, 24 (29.2\%) had dyslipidemia, 29 (35.3\%) had hypertension and 9 (10.9\%) had type 2 diabetes mellitus. Patients with MetS had higher mean values of waist circumference, systolic and diastolic blood pressures than those of patients without MetS $(p=0.03, p=0.01, p=0.05$, respectively).

Among patients with MetS, 21.1\% were smokers and 13.7\% informed alcohol consumption. However, 19.0\% of control subjects were smokers and only 15.1\% of them consumed alcohol ( $p=0.65, p=0.90)$ (Table 1 ).

In elderly patients with MetS, mean levels of ferritin, hs-CRP, fasting glucose, fasting insulin and HOMA were found to be $72.9 \pm 33.1 \mathrm{ng} / \mathrm{ml}, 0.90 \pm 0.01,99.1 \pm 20.1 \mathrm{mg} / \mathrm{dl}, 13.4 \pm 1.1 \mu \mathrm{U} / \mathrm{l}, 3.0 \pm 0.1$, respectively. Ferritin, hs-CRP, fasting glucose, fasting insulin and HOMA were found to be $54.1 \pm 33.1 \mathrm{ng} / \mathrm{ml}, 0.67 \pm 0.1$, $91.9 \pm 17.0 \mathrm{mg} / \mathrm{dl}, 8.4 \pm 2.7 \mu \mathrm{U} / \mathrm{l}, 2.71 \pm 0.9$, in the other elderly patients, $(p=0.0012),(p=0.70),(p=0.70),(p$ $=0.003),(p=0.80)$ respectively (Table 2$)$.

Mean levels of ferritin were positively correlated with diastolic ( $\mathrm{r}=0.850, p=0.03$ ), systolic blood pressures ( $\mathrm{r}=0.700, p=0.02)$, and fasting insulin $(\mathrm{r}=0.444, p=0.003)$ in elderly with MetS. However, there was no correlation between ferritin and hs-CRP levels in elderly with MetS ( $\mathrm{r}=0.450, p=0.06)$. And also, mean levels of ferritin were positively correlated with HOMA $(r=0.775, p=0.02)$ in control.

\section{Discussion}

Increasing life expectancy is a worldwide phenomenon and has led to a progressive increase in the proportion of

Table 1. Demographic and anthropometric characteristics of elderly patients with metabolic syndrome and control were shown.

\begin{tabular}{cccc}
\hline Parameters & Metabolic Syndrome $(\mathbf{n}=\mathbf{3 9})$ & Control (n= 82) & $\boldsymbol{p}$ \\
\hline Age (years) & $69.5 \pm 21.1$ & $61.1 \pm 17.8$ & 0.80 \\
Smokers, (\%) & $21.1 \%$ & $19.0 \%$ & 0.65 \\
Smoking pocket/year & $9.1 \pm 1.5$ & $6.1 \pm 0.9$ & 0.70 \\
Alcohol consumption, no (\%) & $13.7 \%$ & $15.1 \%$ & 0.90 \\
Body weight (kg) & $70.0 \pm 14.8$ & $66.0 \pm 19.1$ & 0.70 \\
Body Mass Index (kg/m $\left.{ }^{2}\right)$ & $30.4 \pm 5.8$ & $26.1 \pm 9.8$ & 0.95 \\
Waist circumference (cm) & $109.5 \pm 23.1$ & $81.2 \pm 15.5$ & $0.03^{*}$ \\
Systolic Blood Pressure (mmHg) & $145.0 \pm 34.0$ & $131.9 \pm 27.1$ & $0.01^{*}$ \\
Diastolic Blood Pressure (mmHg) & $69.9 \pm 15.3$ & $58.1 \pm 14.8$ & $0.05^{*}$ \\
\hline
\end{tabular}

${ }^{*}$ Reflecting significant difference at the level of $p<0.05$.

Table 2. Biochemical characteristics of elderly patients with metabolic syndrome and control were shown.

\begin{tabular}{|c|c|c|c|}
\hline Parameters & Metabolic Syndrome $(\mathrm{n}=39)$ & Control $(\mathrm{n}=82)$ & $p$ \\
\hline Fasting glucose (mg/dl) & $99.1 \pm 20.1$ & $91.9 \pm 17.0$ & 0.70 \\
\hline Fasting insulin $(\mu \mathrm{U} / \mathrm{ml})$ & $13.4 \pm 1.1$ & $8.4 \pm 2.7$ & 0.003 \\
\hline HOMA-IR & $3.0 \pm 0.1$ & $2.71 \pm 0.9$ & 0.80 \\
\hline T-Cholesterol (mg/dl) & $241.5 \pm 35.1$ & $206.8 \pm 29.1$ & 0.90 \\
\hline HDL-Cholesterol (mg/dl) & $39.1 \pm 10.7$ & $41.8 \pm 13.1$ & 0.80 \\
\hline LDL-Cholesterol (mg/dl) & $140.0 \pm 21.0$ & $131.9 \pm 27.1$ & $0.04^{*}$ \\
\hline Triglyceride (mg/dl) & $138.1 \pm 22.5$ & $125.3 \pm 31.8$ & $0.001^{*}$ \\
\hline Hematocrit (\%) & $34.0 \pm 3.1$ & $35.1 \pm 7.1$ & $0.01^{*}$ \\
\hline Ferritin (mg/dl) & $72.9 \pm 33.1$ & $54.1 \pm 33.1$ & $0.0012^{*}$ \\
\hline hs-CRP (mg/dl) & $0.90 \pm 0.01$ & $0.67 \pm 0.1$ & 0.70 \\
\hline
\end{tabular}

\footnotetext{
${ }^{*}$ Reflecting significant difference at the level of $p<0.05$.
} 
elderly people within the population [1]. The prevalence of MetS in different regions depends on defining criteria. The unhealthy lifestyle which is defined by sedentary character of people and unhealthy diets is significantly associated with MetS [22]. The metabolic syndrome is directly related to the accumulation of visceral adiposity in middle age associated with overeating and a decline in exercise. It has been estimated that $15 \%$ to $20 \%$ of persons aged over 70 years have metabolic syndrome [23]. Among the elderly population, the prevalence of MetS was reported to be higher in Turkey (61.7\%) [24]. Likewise, the prevalence of MetS in Turkish adults aged 40 years or over, currently standing at $53 \%$, shows significant differences across geographic regions, being highest in the two southern regions and lowest in the Aegean region [25]. In the present study, we found that the frequency of MetS in elderly was 32.2\%. This finding might be different from other studies due to nutrition and physical activity characteristics in our region.

Serum ferritin concentration is considered to be a good measure of body iron stores in healthy people [11]. Higher levels of ferritin at baseline were associated with the metabolic syndrome [26], hyperinsulinemia, high HOMA-IR, and low HOMA\%B and with an increased prevalence of the MetS [27]. To previous knowledge, most common defect in patients with an earlier stage of damage induced by iron overload is liver mediated insulin resistance [28]. And also, Haap et al. [14] reported that reduced hepatic insulin extraction, resulting in hyperinsulinemia correlated with the degree of iron overload. In some studies, it has been shown that there are positive correlations between levels of serum ferritin and those of fasting glucose, insulin, and glycosylated hemoglobin [29]-[32]. An independent and significant positive association between higher plasma ferritin, and increased risk of developing type 2 diabetes has been reported in middle-aged and elderly adults [33]. In a recent study, it was found that, dyslipidemia, obesity, and insulin resistance might be important risk factors for higher serum ferritin levels in the elderly [34]. Furthermore, Oshaug et al. [35] have found that diastolic blood pressure was a significant predictor for serum ferritin levels. In another study, Canturk et al. [36] showed that there was an independent positive association between serum ferritin concentrations and markers of glucose homeostasis. In another study, Salonen et al. [37] reported that serum ferritin concentrations had a significant positive correlation with blood glucose, serum triglycerides, and serum apolipoprotein B concentrations, and an inverse correlation with serum HDL cholesterol. However, in the present study, we found that there were positive correlations between ferritin and some of metabolic syndrome components such as diastolic and systolic blood pressures as well as fasting insulin levels, but not with lipid levels in elderly with MetS. And also, we found a positive correlation between ferritin and HOMA-IR levels in the control group. Those findings showed that there was association between serum ferritin levels and insulin resistance in elderly with and without MetS.

Subclinical inflammation, which is usually observed in individuals with obesity and the metabolic syndrome, is associated with increased risk of type 2 diabetes [38]. And also, increased body iron may contribute to insulin resistance via chronic inflammation and oxidative stress [39]. In many studies [11] [40], it has been suggested that formation of hydroxyl radicals catalyzed by iron might be associated with incident diabetes. Because, highly active radicals could attack cell membrane lipids, proteins, and DNA and cause tissue damage. In addition, oxidative stress may impair insulin secretion and insulin extraction [39]. Based on the data from the study of Sharifi et al. [40], elevation in serum ferritin levels could be seen in pre-diabetes stage, before the occurrence of an overt diabetes mellitus. Likewise, González et al. [15], reported that MetS and insulin resistance are associated with elevated serum CRP and ferritin levels. However, to our findings, there was no statistically significant difference between the two groups with regard to hs-CRP levels. And also no correlations were found between ferritin and hs-CRP levels in elderly with and without MetS, probably because of sample size. Future studies are needed in the elderly patients with MetS.

In summary, mean levels of ferritin were increased in elderly patients with metabolic syndrome. And also, ferritin levels were positively correlated with systolic and diastolic blood pressures as well as fasting insulin but not with hs-CRP levels in elderly patients with metabolic syndrome.

\section{References}

[1] Wang, J.L. and Shaw, N.S. (2005) Iron Status of the Taiwanese Elderly: The Prevalence of Iron Deficiency and Elevated Iron Stores. Asia Pacific Journal of Clinical Nutrition, 14, 278-284.

[2] Heeney, M.M. and Andrews, N.C. (2004) Iron Homeostasis and İnherited Iron Overload Disorders: An Overview. Hematology/Oncology Clinics of North America, 18, 1379-1403. http://dx.doi.org/10.1016/j.hoc.2004.06.018

[3] Cook, J.D., Flowers, C.H. and Skikne, B.S (2003) The Quantitative Assessment of Body Iron. Blood, 101, 3359-3364. 
http://dx.doi.org/10.1182/blood-2002-10-3071

[4] Park, S.K., Choi, W.J., Oh, C.M., Kim, J., Shin, H. and Ryoo, J.H (2014) Association between Serum Ferritin Levels and the Incidence of Obesity in Korean Men: A Prospective Cohort Study. Endocrine Journal, 61, 215-224.

[5] Sheu, W.H., Chen, Y.T., Lee, W.J., Wang, C.W. and Lin, L.Y. (2003) A Relationship between Serum Ferritin and the Insulin Resistance Syndrome Is Present in Non-Diabetic Women but Not in Non-Diabetic Men. Clinical Endocrinology (Oxford), 58, 380-385. http://dx.doi.org/10.1046/j.1365-2265.2003.01729.x

[6] Kim, C.H., Kim, H.K., Bae, S.J., Park, J.Y. and Lee, K.U. (2011) Association of Elevated Serum Ferritin Concentration with İnsulin Resistance and Impaired Glucose Metabolism in Korean Men and Women. Metabolism, 60, 414420. http://dx.doi.org/10.1016/j.metabol.2010.03.007

[7] Jehn, M., Clark, J.M. and Guallar, E. (2004) Serum Ferritin and Risk of the Metabolic Syndrome in US Adults. Diabetes Care, 27, 2422-2428. http://dx.doi.org/10.2337/diacare.27.10.2422

[8] Park, S.K., Ryoo, J.H., Kim, M.G. and Shin, J.Y. (2012) Association of Serum Ferritin and the Development of Metabolic Syndrome in Middle-Aged Korean Men: A 5-Year Follow-Up Study. Diabetes Care, 35, 2521-2526. http://dx.doi.org/10.2337/dc12-0543

[9] Jiang, R., Manson, J.E., Meigs, J.B., Ma, J., Rifai, N. and Hu, F.B. (2004) Body Iron Stores in Relation to Risk of Type 2 Diabetes in Apparently Healthy Women. Journal of the American Medical Association, 291, 711-717. http://dx.doi.org/10.1001/jama.291.6.711

[10] Haidari, M., Javadi, E., Sanati, A., Hajilooi, M. and Ghanbili, J. (2001) Association of Increased Ferritin with Premature Coronary Stenosis in Men. Clinical Chemistry, 47, 1666-1672.

[11] Wolff, S.P. (1993) Diabetes Mellitus and Free Radicals: Free Radicals, Transition Metals and Oxidative Stress in the Aetiology of Diabetes Mellitus and Complications. British Medical Bulletin, 49, 642-652.

[12] Williams, M.J., Poulton, R. and Williams, S. (2002) Relationship of Serum Ferritin with Cardiovascular Risk Factors and İnflammation in Young Men and Women. Atherosclerosis, 165, 179-184. http://dx.doi.org/10.1016/S0021-9150(02)00233-2

[13] Fernandez-Real, J.M., Ricart-Engel, W., Arroyo, E., Balanca, R., Casamitjana-Abella, R., Cabrero, D., FernándezCastañer, M. and Soler, J. (1998) Serum Ferritin as a Component of the Insulin Resistance Syndrome. Diabetes Care, 21, 62-68. http://dx.doi.org/10.2337/diacare.21.1.62

[14] Haap, M., Fritsche, A., Mensing, H.J., Haring, H.U. and Stumvoll, M. (2003) Association of High Serum Ferritin Concentration with Glucose Intolerance and Insulin Resistance in Healthy People. Annals of Internal Medicine, 139, 869-371. http://dx.doi.org/10.7326/0003-4819-139-10-200311180-00029

[15] Gonzalez, A.S., Guerrero, D.B., Soto, M.B., Diaz, S.P., Martinez-Olmos, M. and Vidal, O. (2006) Metabolic Syndrome, Insulin Resistance and the Inflammation Markers C-Reactive Protein and Ferritin. European Journal of Clinical Nutrition, 60, 802-809. http://dx.doi.org/10.1038/sj.ejcn.1602384

[16] Gastaldelli, A., Perego, L., Paganelli, M., Sesti, G., Hribal, M., Chavez, A.O., Defronzo, R.A., Pontiroli, A. and Folli, F. (2009) Elevated Concentrations of Liver Enzymes and Ferritin İdentify a New Phenotype of İnsulin Resistance: Effect of Weight Loss after Gastric Banding. Obesity Surgery, 19, 80-86.

[17] Tuomainen, T.P., Nyyssönen, K., Salonen, R., Tervahauta, A., Korpela, H., Lakka, T., Kaplan, G.A. and Salonen, J.T. (1997) Body Iron Stores Are Associated with Serum İnsulin and Blood Glucose Concentrations. Population Study in 1013 Eastern Finnish Men. Diabetes Care, 20, 426-428. http://dx.doi.org/10.2337/diacare.20.3.426

[18] Jung, C.H., Lee, M.J., Hwang, J.Y., Jang, J.E., Leem, J., Park, J.Y., Lee, J., Kim, H.K. and, Lee, W.J. (2013) Elevated Serum Ferritin Level Is Associated with the İncident Type 2 Diabetes in healthy Korean Men: A 4 Year Longitudinal Study. PLOS ONE, 8, Article ID: e75250.

[19] Ford, E.S., Giles, W.H. and Dietz, W.H. (2002) Prevalence of the Metabolic Syndrome among US Adults. Journal of the American Medical Association, 287, 356-359. http://dx.doi.org/10.1001/jama.287.3.356

[20] Akbartabartoori, M., Lean, M.E. and Hankey, C.R. (2006) Smoking Combined with Overweight or Obesity Markedly Elevates Cardiovascular Risk Factors. European Journal of Preventive Cardiology, 13, 938-946. http://dx.doi.org/10.1097/01.hjr.0000214613.29608.f5

[21] Matthews, D.R., Hosker, J.P., Rudenski, A.S., Naylor, B.A., Treacher, D.F. and Turner, R.C. (1985) Homeostasis Model Assessment: Insulin Resistance and Beta-Cell Function from Fasting Plasma Glucose and Insulin Concentrations in Man. Diabetologia, 28, 412-419. http://dx.doi.org/10.1007/BF00280883

[22] Pădure, L., Ignat, I.S., Eşanu, I. and Hurjui, J. (2011) Prevalence of Metabolic Syndrome in a Population of Transport Workers-Prospective Study. Revista Medico-chirurgicala a Societatii de Medici si Naturalisti din Iasi, 115, 10481051.

[23] John, E. and Morley, J.E. (2004) The Metabolic Syndrome and Aging. Journals of Gerontology Series A: Biological 
Sciences and Medical Sciences, 59, M139-M142. http://dx.doi.org/10.1093/gerona/59.2.M139

[24] Akbulut, G., Koksal, E., Bilici, S., Tek, N.A., Yildiran, H., Karadag, M.G. and Sanlier, N. (2001) Metabolic Syndrome (MS) in Elderly: A Cross Sectional Survey. Archives of Gerontology and Geriatrics, 53, e263-e266. http://dx.doi.org/10.1016/j.archger.2010.11.021

[25] Onat, A., Yüksel, M., Köroğlu, B., Gümrükçüoğlu, H.A., Aydın, M., Cakmak, H.A., Karagöz, A. and Can, G. (2013) Turkish Adult Risk Factor Study Survey 2012: Overall and Coronary Mortality and Trends in the Prevalence of Metabolic Syndrome. Turk Kardiyoloji Dernegi Arsivi, 41, 373-378. http://dx.doi.org/10.5543/tkda.2013.15853

[26] Abril-Ulloa, V., Flores-Mateo, G., Solà-Alberich, R., Manuel-y-Keenoy, B. and Arija, V. (2014) Ferritin Levels and Risk of Metabolic Syndrome: Meta-Analysis of Observational Studies. BMC Public Health, 14, Article ID: 483. http://dx.doi.org/10.1186/1471-2458-14-483

[27] Vari, I.S., Balkau, B., Kettaneh, A., André, P., Tichet, J., Fumeron, F., Caces, E., Marre, M., Grandchamp, B., Ducimetière, P. and DESIR Study Group (2007) Ferritin and Transferrin Are Associated with Metabolic Syndrome Abnormalities and Their Change over Time in a General Population: Data from an Epidemiological Study on the Insulin Resistance Syndrome (DESIR). Diabetes Care, 30, 1795-1801. http://dx.doi.org/10.2337/dc06-2312

[28] Ferrannini, E. (2000) Insulin Resistance, Iron, and the Liver. Lancet, 355, 2181-2182. http://dx.doi.org/10.1016/S0140-6736(00)02397-7

[29] Montonen, J., Boeing, H., Steffen, A., Lehmann, R., Fritsche, A., Joost, H.G., Schulze, M.B. and Pischon, T. (2012) Body Iron Stores and Risk of Type 2 Diabetes: Results from the European Prospective Investigation into Cancer and Nutrition (EPIC)-Potsdam Study. Diabetologia, 55, 2613-2621. http://dx.doi.org/10.1007/s00125-012-2633-y

[30] Andrews, N.C. (1999) Disorders of Iron Metabolism. New England Journal of Medicine, 341, 1986-1995. http://dx.doi.org/10.1056/NEJM199912233412607

[31] Beard, J.L. (2001) Iron Biology in İmmune Function, Muscle Metabolism and Neuronal Functioning. Journal of Nutrition, 131, 568-579.

[32] Wilson, J.G., Lindquist, J.H., Grambow, S.C., Crook, E.D. and Maher, J.F. (2003) Potential Role of İncreased Iron Stores in Diabetes. American Journal of the Medical Sciences, 325, 332-339. http://dx.doi.org/10.1097/00000441-200306000-00004

[33] Sun, L., Zong, G., Pan, A., Ye, X., Li, H., Yu, Z., Zhao, Y., Zou, S., Yu, D., Jin, Q., Hu, F.B. and Lin, X. (2013) Elevated Plasma Ferritin Is Associated with İncreased İncidence of Type 2 Diabetes in Middle-Aged and Elderly Chinese Adults. Journal of Nutrition, 143, 1459-1465. http://dx.doi.org/10.3945/jn.113.177808

[34] Li, B., Lin, W., Lin, N., Dong, X. and, Liu, L. (2014) Study of the Correlation between Serum Ferritin Levels and the Aggregation of Metabolic Disorders in Non-Diabetic Elderly Patients. Experimental and Therapeutic Medicine, 7, 1671-1676.

[35] Oshaug, A., Bugge, K.H., Bjonnes, C.H., Boreh-lohnsen, B. and Neslein, I.L. (1995) Associations between Serum Ferritin and Cardiovascular Risk Factors in Healthy Young Men: A Cross Sectional Study. European Journal of Clinical Nutrition, 49, 430-438.

[36] Canturk, Z., Cetinarslan, B., Tarkun, I. and Canturk, N.Z. (2003) Serum Ferritin Levels in Poorly- and Well-Controlled Diabetes Mellitus. Endocrine Research, 29, 299-306. http://dx.doi.org/10.1081/ERC-120025037

[37] Salonen, J.T., Nyyssonen, K., Korpela, H., Tuomilehto, J., Seppanen, R. and Salonen, R. (1992) High Stored Iron Levels Are Associated with Excess Risk of Myocardial İnfarction in Eastern Finnish Men. Circulation, 86, 803-811. http://dx.doi.org/10.1161/01.CIR.86.3.803

[38] Lee, C.C., Adler, A.I., Sandhu, M.S., Sharp, S.J., Forouhi, N.G., Erqou, S., Luben, R., Bingham, S., Khaw, K.T. and Wareham, N.J. (2009) Association of C-Reactive Protein with Type 2 Diabetes: Prospective Analysis and MetaAnalysis. Diabetologia, 52, 1040-1047. http://dx.doi.org/10.1007/s00125-009-1338-3

[39] Oberley, L.W. (1988) Free Radicals and Diabetes. Free Radical Biology and Medicine, 5, 113-124. http://dx.doi.org/10.1016/0891-5849(88)90036-6

[40] Sharifi, F., Nasab, N.M. and Zadeh, H.J. (2008) Elevated Serum Ferritin Concentrations in Prediabetic Subjects. Diabetes and Vascular Disease Research, 5, 15-18. http://dx.doi.org/10.3132/dvdr.2008.003 


\section{Abbreviations}

HOMA-IR = Homeostasis model assessment-insulin resistance;

LDL = Low-density lipoprotein;

HDL= High-density lipoprotein;

hs-CRP = High sensitivity C-reactive protein. 
Scientific Research Publishing (SCIRP) is one of the largest Open Access journal publishers. It is currently publishing more than 200 open access, online, peer-reviewed journals covering a wide range of academic disciplines. SCIRP serves the worldwide academic communities and contributes to the progress and application of science with its publication.

Other selected journals from SCIRP are listed as below. Submit your manuscript to us via either submit@scirp.org or Online Submission Portal.
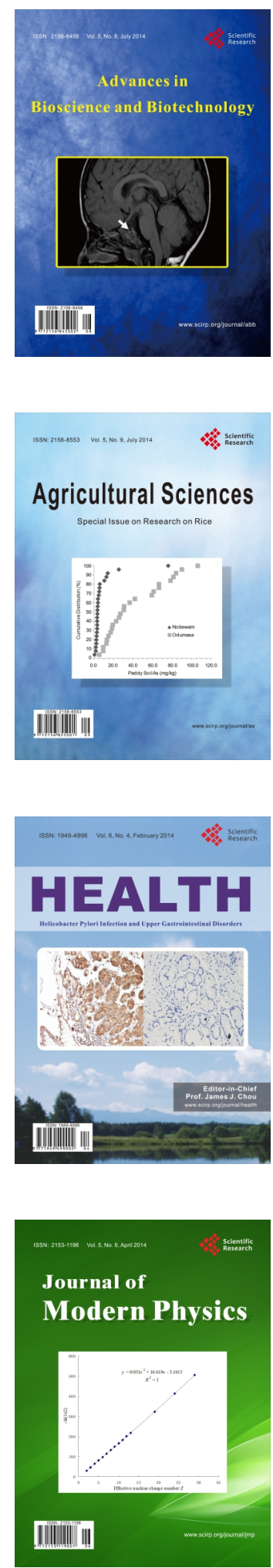
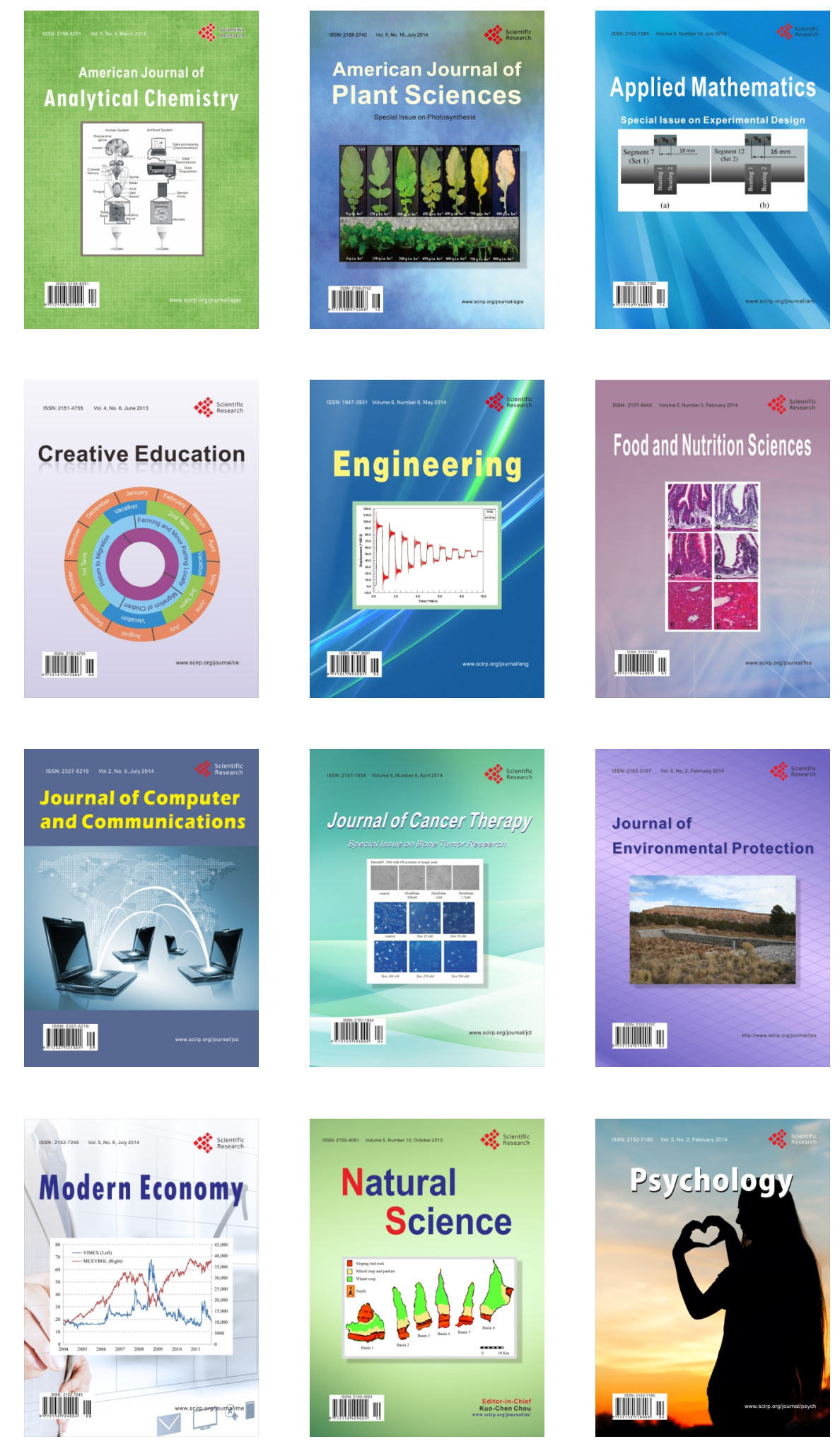